\title{
'Home is like...': A conversation about poetry and longing for home
}

\author{
Marcela Duran \\ York University \\ mduran@edu.yorku.ca \\ Dahabo Ibrahim \\ dahabolucky003@gmail.com \\ Deko Shahow \\ dekogaiye@gmail.com \\ Mohamed Hajir Siyat \\ hajir0703@gmail.com
}

\begin{abstract}
This article presents a WhatsApp dialogue between student writers and their teacher discussing the poetry and commentary they wrote during an online course the year before. The students are refugees living in the containment of an UNHCR camp in Dadaab, Kenya. Throughout the dialogue, the longing for a lost home and the cultural relevance and permanence of poetry in their lives as Somalis, are evident.
\end{abstract}

Keywords: Home, online dialogue, poetry, refugee camps, Somalia

\section{Introduction}

This article presents two complementary and interwoven essays in which distinct voices, symbolically, sing and soar from their respective cages. In the first essay, the university professor, Marcela Duran, in a smooth rich, alto voice, sings of the theoretical and practical frameworks and lived experiences that have influenced her teaching (in fall 2018), the online university course to students in a Kenyan refugee camp. In effect, Marcela becomes the agent provocateur who encourages the students to soar to the skies by writing poetry. By doing so, their hearts, minds and spirits are free, despite being physically restricted to living in the camp. In the second essay, the three student poets begin by singing of the personal impacts of listening to and viewing a video of well known, British-Somali poet, Warsan Shire (2011), reciting her poem: Home. As importantly, the students make explicit in the expanding interactive discussion with Marcela, the historical and contemporary significance of poetry in the Somalian culture. 


\section{ESSAY 1}

\section{Marcela Duran}

The ideas for this article originated from an online conversation about poetry I had with Dahabo Ibrahim, Deko Shahow and Mohamed Hajir Siyat. The conversation was a WhatsApp chat that later became the basis for our writing.

I met Dahabo, Deko and Mohamed as students in a course I taught the fall of 2018. In the conversation, a year after the course had finished, we revisited poems they had written after they had heard and viewed a video of Warsan Shire reciting her poem Home. Collectively, we read again their work and we dialogued about their decisions and inspiration to write as they did. Following that conversation, we engaged in an exchange about their cultural heritage as Somalis and their understanding of the importance of poetry for Somalis. Throughout the exchange, their references to the fact they had lived most of their lives in the containment of a refugee camp, brought to the forefront for me, how the depth of their culture lived in their souls as transmitted to them by their elders in community gatherings or in the warmth of their own homes.

The course where we met, Multilingualism and Multiculturalism in Educational Contexts, is an undergraduate online course and is one of the offerings of the Bachelor of Arts degree in Education Studies, from the Faculty of Education at York University. The cohort of students who registered in this course the fall of 2018, were part of the BHER* (Borderless Higher Education for Refugees) program, and were completing their Bachelor of Arts degrees. The students are refugees living in the UNHCR camps located in Dadaab and Kakuma in Northern Kenya, Africa. All of the students that took the course were residents of the Dadaab and/or Kakuma camps. The three contributing authors have Somali origins, however, there were students from a diversity of origins in the class. Of the 29 students registered, 22 were Somali nationals, 6 had been born in Ethiopia and one student in Rwanda. The format of the course was online and there were no students from York University in Toronto, Canada, registered in it. Most of the work was online via the course platform (Moodle), and students and I met as a class via Zoom communication for a one-hour tutorial each Friday at 7:00 a.m. Toronto time, 2:00 p.m. local Kenya time.

The course engaged students in an exploration of first and second language acquisition and the importance of first language learning and maintenance for both cognitive and emotional development. As part of the work, students were asked to explore the role of languages in their personal lives through writing short pieces about first language learning, schooling and poems about home memories.

In my teaching at the Faculty of Education at York University, I have often incorporated poetry writing in my courses. Pedagogically, my hope has been to encourage future teachers to think of classrooms as sites of community-building where everybody, teachers and students, share with each other important aspects of their lives, making the learning adventure a communal task. Personal expression through poetry lends itself to that. I was originally inspired to take this approach after reading the article, "Where I'm from, inviting students' lives into the classroom" that Linda Christensen, an American teacher, published in the book Beyond Heroes and Holidays: A Practical Guide to K-12 Anti-Racist, Multicultural Education \& Staff Development

Cultural and Pedagogical Inquiry, Summer 2020, 12(1), pp. 134-148

ISSN 1916-3460 (C) 2020 University of Alberta

http://ejournals.library.ualberta.ca/index.php/cpi/index 
(2008). In her article, Linda tells how she asked her students to read the poem 'Where I'm From' by George Ella Lyon and invited them to write poems using the line 'I am from' as a prompt.

As I was planning for the course, late in the summer of 2018, Mohamed Duale**, shared with me Warsan Shire's video of her poem Home (Home is the Barrel of the Gun). I was so moved by the video that I decided to include it as one of the videos that would be available to the class, since it touched on themes that would be discussed throughout the course. I thought we could use it as inspiration to talk about home and community. I was also fortunate to find in York's video library, a video of a conversation between the Somali writer Nuruddin Farah and the Nigerian writer Chinua Achebe where they discuss language, second language and poetry in the first language that I also added to the class platform (Moodle). These two videos were often referred to by students in their writings for the course. While I knew little about Somalia and Somali poets, I had learned through my teaching, that poetry was a powerful vehicle to share feelings and emotions in a class. Also, I had come to Canada, from Chile, as a refugee myself many years ago and I felt that, even though our experiences were very different, I could at least empathize with the feeling many of my students might have of being away and excluded from Home.

I was hoping for writings that would speak about home and most probably would refer to home language and the loss of it. I was overwhelmed by the quality and depth of the poems and by the writings of the students who took this course.

Student-authors Dahabo Ibrahim, Deko Shahow and Mohamed Hajir Siyat have agreed to participate in this post-course project in the form of a dialogue. As the dialogue progresses, they share information about their lives and aspirations as well as their views on poetry and culture. The communication was online using our cell phones and the WhatsApp application. We first review the poems they wrote during the course and they give their opinions about their writing prompted by my questions. In a second section, we engage in a conversation about Somali poetry in the Dadaab refugee camps, the longing for lost homes and maintenance of cultural heritage. The conversational style of our work is inspired by Paulo Freire's and Donaldo Macedo's dialogical style used in the book Literacy: Reading the Word and the World (1987:94-159). In these chapters, Freire and Macedo present their views about literacy in the form of a dialogue. Similarly, to the exchanges in their dialogue, information about culture and livelihoods seems to flow naturally in ours and we all learn from each other.

\section{Introducing the Student Authors}

Our participation reflects the conversations that we, BHER students, Dahabo Ibrahim, Mohamed Hajir Siyat, Deko Shahow and our professor Marcela Duran engaged in. As participants in this project, we agreed to approach our writing as a dialogue. Our hope is that the content of our conversations with Marcela, will speak clearly about life in Dadaab's UNHCR refugee camps, the meaning of our longing for home, and the role of poetry in our lives.

We communicated via WhatsApp and we called our chat Poetic Friends. We all read the poems and reflections that each had contributed during the course. Marcela read again our poetry and the notes we had written in the course's website. Our WhatsApp chat included questions about reasons for our writing as well as our ideas about the importance of poetry for Somalis. We focused the conversation on our experiences as students of Somali origin and our ideas about

Cultural and Pedagogical Inquiry, Summer 2020, 12(1), pp. 134-148

ISSN 1916-3460 @ 2020 University of Alberta

http://ejournals.library.ualberta.ca/index.php/cpi/index 
Somali poetry. Marcela asked us to become involved in this spin-off project as she thought that our poems were representative of the themes present in the poetry that had been written by the students in the online course.

We felt it was important to begin our conversation by reading or viewing again the poem Home as it served as inspiration and reflection point in class. However, since we understand we cannot reproduce the entire poem in a journal article, we invite the reader to click this link and take time at this point to listen and view the video of Warsan Shire's 'Home'. https://www.youtube.com/watch?v=ybTM-aaJxS0

\section{ESSAY 2}

Marcela: Mohamed, Dahabo and Deko; after listening and reading Warsan Shire's poem Home one more time, I went back and read the comments and poems you wrote in the fall of 2018. I invite you now to a dialogue about what you wrote then, and discuss your ideas about it a year after the course ended.

\section{MOHAMED'S POEM}

Marcela: Mohamed, on October 19, 2018, you wrote:

"The poem Home written by Warsan Shire reflects how her home was once a perfect and peaceful place to live. I have listened and I enjoyed it so much. She started her poem with -'No one leaves home unless home is the mouth of a shark.'- This statement indicates that there is no place like home because wherever you go, home is the best place. She also compares home with the mouth of a shark because of the danger in her home country. She would have liked to remain home but she could not, because her home is the most awful place to be and therefore, she has to escape the danger to save her life. Warsan mentioned in her poem the insults and challenges she faced as a refugee. 'They called you asylum seekers and dirty immigrants who destroyed their countries and want to mess up our beautiful country'.

Discrimination is the order of the day in refugee camps like Dadaab. Personally, as a person in exile, everything Warsan pointed out in her poem is similar to things I am experiencing right now in Dadaab refugee camp, emotionally, psychologically and physically.

Above all, I am thankful to, the Government of Kenya and UNHCR for having me as a refugee. However, being a refugee, you are restricted and treated as a second-class human being. Movement and work permits are restricted just because you are not a citizen. Individually, I am delighted with the success Warsan had in spite of her past difficulties. As a refugee, we share a lot of things and her poem speaks much about our experiences here in Dadaab."

Marcela: It seems to me that in your poem, you decided to set aside the sadness and instead you chose to write about your memories of a sweet home and only in the last stanza you say, with great sadness, 'once lost can't be regained'.

Cultural and Pedagogical Inquiry, Summer 2020, 12(1), pp. 134-148

ISSN 1916-3460 () 2020 University of Alberta

http://ejournals.library.ualberta.ca/index.php/cpi/index 


\title{
Sweet is home
}

\author{
by Mohamed Hajir Siyat
}

No trauma,

No nightmares,

Observed are my rights -

Next to daddy: I sit.

A mug of chocolate drink - I sip.

No discrimination:

Such is a sweet home

Well ironed clothes,

Clean, neat and tidy;

From my Mom I receive:

Such is a sweet home.

Playing children,

Beautiful chicken -

Amazing stories,

And happy babies -

Such is a sweet home.

Wise elders

Wife makers

Well thought ideas:

Such is a sweet home.

Moral virtues

Memorable moments

Such is a sweet home -

Home is like fresh camel milk;

During a dry season.

Once lost, can't be regained.

Such is a sweet home 
Marcela: Why did you decide to write a poem about home in this way Mohamed?

Mohamed: I wrote the poem because it is my hobby. It is the only way I can express the powerful feelings, or the ideas and thoughts going through my mind. Besides, it is a way of communicating to others without writing much.

Poems are part and parcel of a Somali's life and thus, inevitable. For instance, when performing hard tasks, it is our practice to recite long poems to encourage us. Many of the poems I have read talk about home. You will soon agree with me that everyone loves their home country. You can figure the picture of a child who misses his home for more than twenty years. How lonely, uncomfortable it can be.

One thing that should be mentioned is that, in the refugee set-up, there are many demanding circumstances. One cannot get all the necessary human wants. One of them being lack of freedom of movement. The refugees in the camps are restricted like animals in a cage. One cannot travel and explore the other parts of the country (Kenya), unlike one who is in his own country.

Another factor that makes me write about home is that refugees are being discriminated [against]. They are regarded as people who cannot bring new ideas to the world. People have the notion that one who is being controlled is psychologically, physically or emotionally restricted. In my own home country, I would be a recognized poet and my ideas would be valid. In conclusion, my dream is to go back home and re-build the nation. To be a liberated young scholar and poet whose thoughts are valid. So, many of my poems are directly reflecting my thoughts/dreams about my lovely home. My poems are an anticipation of the success of young people.

\section{DAHABO'S POEM}

Marcela: Dahabo, on the same date as Mohamed, you commented on your listening to Warsan Shire's 'Home' and later wrote a poem taking a very different perspective, one where you decided to write about the only home you have known, that of a refugee camp in Dadaab:

"In the video, Warsan Shire talks about the refugee people who fled from their homeland especially because of prolonged war, political issues and others, which resulted in moving to neighboring countries. In the Dadaab context, we fled the civil war that broke our home and came to Kenya as asylum seekers where we got assistance, but we feel sad because we lost many of our beloved ones and others. None of us chose to become refugees. Where we are living, we are not allowed to move beyond Dadaab. Being a refugee is not always right and there are still many challenges, like all forms of violence, even in the camps. By the time we came to Kenya, we had lost many children due to malnutrition, cholera and climate change. So for now, we are educated and learn a lesson in being a refugee. As in the old saying, 'East and West homeland is still the best'.

Somali language is our first language but here it is English and Kiswahili. Children below 15 yrs. are not able to write in their mother tongue but they can speak it fluently; this is another challenge brought by the destruction and wars to our people. My parents fled

Cultural and Pedagogical Inquiry, Summer 2020, 12(1), pp. 134-148

ISSN 1916-3460 () 2020 University of Alberta

http://ejournals.library.ualberta.ca/index.php/cpi/index 
Somalia immediately after the downfall of the Mohamed Ziad Barre's regime when I was just two years old and therefore, I had little or no memory about my country Somalia. Furthermore, I have never seen that country with my own eyes and that is why I decided to write a poem about Dadaab, specifically Dagahaley Refugee camp, where I have been living for the last 26 years."

\section{Dadaab My Home}

by Dahabo Ibrahim

Home for hopeless

Like me \& thousand others

Exactly two decades and a half ago

When my parents were in despair

I never knew only suffered the long journey

Tired of walking all that distance

My younger brother on my mother's back

I being right on her chest

With no water and food to taste

We never cared about facility

But escaping from massive hostility

Where thousand got killed

Thousand others detained

Thank you Dadaab for hosting me

For schooling me

It is because of you that I am who I am today

You will always stay in my heart

With all the bad and good events

Dadaab the only place I call home

The place where I starve

Seen all meanings of life

Including education to strive

Had seen all the ups and downs of life

Have nothing to regret for

For living all those years here

You are even better than Somalia

The country where I was born

Later turned into war torn

You will always be in my heart

Whether things go wrong or go right. 
Marcela: Dahabo, Home for you here has a different meaning. It reflects, I think, another side of being a refugee. You express the ambivalence of having left a homeland of which you have little memory. The experience for you has been life in a camp, a refugee's home, which although difficult and not as hospitable, is still the only home you know and a home that has helped you become who you are today.

Would you like to say more about why you decided to write the poem you wrote?

Dahabo: The main reason that made me write that poem was:

Since we arrived to Kenya in 1992, we have hoped to go back to our home country and learn the culture, poems and traditional dances of my home, because those are Somali ways of life. Unfortunately, the situation that the country has undergone destroyed that hope in my heart. I have grown up in an environment full of harsh life where there have been shortages of food. We human beings, displaced by the war, lost our identities and became refugees. The government of Kenya restricts our movements. I measure my pain of becoming a hopeless person not only me, but thousands of others.

Lack of identity to most of the people in Dadaab creates low self-esteem. However, Dadaab is still my home where I have faced different obstacles nevertheless, it has taught me how to survive in any circumstance that comes across in my life time. But it can't replace the place where I was born.

\section{DEKO'S POEM}

Marcela: Deko, below is what you wrote last October, after reading 'Home'. Later, in your poem you expressed yet one more aspect of the pain of refuge: the anger and the sorrow for the reality and experience of war. You also wrote both in Somali and English bringing to the forefront the great difficulties of translating emotions and the depth of that which can only be expressed in your home language.

"The poem by Warsan Shire talks more about the problems, challenges, conflicts, war and as well difficulties that one could have experienced in his or her home environment. She clearly explains that there is nothing like home ('East and West home is the best'), or there is nothing equal to home in this world she said: 'no one leaves home unless home chases you, fire, hot blood'. In this statement, she tells us that no one will leave home for pleasure purposes.

She really addressed the 'plight of refugees' as she said no one chooses to be a refugee, immigrant, or asylum seeker; they smell strange to the owners and it means everyone likes to stay in his or her country unless greater circumstances forces you to leave. All this is caused due to lack of political stability, social injustices, central governments, thus citizens prefer to look for a secure place since their home is saying 'leave me, run away from me, anywhere else on this earth is safer than me'.

Warsan Shire was a multilingual speaker who read her work extensively all over Britain and internationally and that makes her to be a multicultural person who left and stayed

Cultural and Pedagogical Inquiry, Summer 2020, 12(1), pp. 134-148

ISSN 1916-3460 ( 2020 University of Alberta

http://ejournals.library.ualberta.ca/index.php/cpi/index 
with different people with diverse culture, religion, language, class, identity, gender etc. Warsan said 'no one puts his or her children in a boat unless water is safer than the land' which means, no one leaves home unless circumstances force you, that is why many young people from Somalia are crossing seas in order to look for a better living as well as the refugees who are in Dadaab area.

The relationship between language, culture and identity is that they depend on each other where language is formed by culture, while culture is impacted and influenced by language thus language and culture shape one's identity and personality. And really, I do feel my first/mother tongue is linked to my cultural and personal identity and also connects because it makes me feel a sense of belonging to my culture. I used to feel frustrated by having to speak or use another language in some situations like school, work, because I usually feel shy to speak and actively participate by doing so. After I listened to Warsan Shire's Poem and the film The Story Telling Class***, I decided to write a Poem and this is what I came up with:

Poem

by Deko Shahow

(Translation into English by Deko Shahow)

The former leaders of Somalia their seatbelts were cut off, cut off

Their people have become destitute

Idiots have cheated both country and the people, the people

Your brother-in-law and his son went beyond the area, the area

Their wives' have worsened the situation, worsened, worsened

The economics didn't harmonize, misuse, misuse

Oppression increased and no mercy at all, at all

The poison they were spreading affected us, affected us

The base of the country and the people were robbed, starved, starved

The people have been unable to withstand his abuse

Slept in his father's home and threw his mother from her home

Threw the Ulama in prison and jailed, killed, tortured, murdered...

The chief leader has demolished the people, the religion and the nation

The Ulama's advice guides to the right path, right path

War demolishes, brings collapse, collapse

Women and children seek peace from the heartbreak, peace, peace

Let us not be undermined, interclan will not be a government, government.

Golden opportunity is on our forehead, dumbfounded, startled

May almighty Allah prevent all sorts of evil from us ...... war, killings, torturing, war-based inter-clan, dishonest government

We need peace, peace, peace. 
I really find it hard to translate from one language to another and it was not easy, and I do think the original's meaning has been altered or even lost. I think the meaning of the message has been not lost but somehow it has changed a little."

Marcela: Deko, in your poem you capture the pain and anger that war and destruction, caused by those insensitive to the suffering of others, inflicted on your people. Your poem seems to be in the tradition of Somali epic poems, in a way that Dahabo's and Mohamed's poems seem to reflect a different tradition, one of lyricism. However, you are all, in different ways speaking about the deep emotional meaning of loss.

\section{SOMALIA A NATION OF POETS}

Marcela: Deko, Mohamed and Dahabo, we have up to this point discussed your poems individually. Now, I invite you to join in the conversation as a group and share with each other, with me and our readers, your beliefs about poetry.

I have read texts and articles about how Somalia is known as a nation of poets. After reading your poems, and what you say about your writing, I would like to follow-up with questions about how you understand Somalia as a nation of poets. I am also curious to find out how your knowledge and love for poetry was transmitted to you, while living in the camp as young people. Was oral poetry part of home and/or community life for you? For example, in Chile, where I was born, poetry is also a very important part of the culture and my father used to recite a long poem to put me to sleep instead of reading a children's book. He also recited long poems on national days and we, as children, liked that very much.

Mohamed: "Somalia is a nation of poets".

The above statement is true because poems in this region have several functions. Many Somali poets used this particular art to communicate to their intended audience. For instance, in the 1900s the technological advancements of today's world weren't there. Therefore, poets would draft their sentiments in form of a poem and send to their recipients who would in turn respond by composing another poem.

Among the most famous contemporary Somali literary intellectuals, we should include writer Nuruddin Farah, a potential Somali Nobel Prize winner, and the poet Asha Lul Mohamud Yussuf, currently living in England. Somali poems are majorly employed to warn or teach a lesson. During weddings and political gatherings, people would group themselves into smaller groups and recite poems of praise.

Maxamed Ibraahin Warsame 'Hadraawi' is remembered for producing many poems. He is one of our great Somali poets. He composed more than 70 lyric songs and 200 epic poems. He is honoured for creating beautiful poems. In 2012, Hadraawi was given the highly prestigious Prince Claus Fund Award.

Hadraawi's poems include: 'The Killing of the She-Camel', 'Life's Essence', 'Amazement', 'Clarity', 'Society' and 'Settling the Somali Language'.

Cultural and Pedagogical Inquiry, Summer 2020, 12(1), pp. 134-148

ISSN 1916-3460 ( 2020 University of Alberta

http://ejournals.library.ualberta.ca/index.php/cpi/index 
When I was young, our grandmother used to call us to gather around the fireplace to narrate epic poems. She would recite long poems and at the end ask us questions pertaining to the poem she had read. Anyone who would not understand was regarded as a 'foolish member of the community whose objective was to eat'. I liked grandmother's narration because she employed paralinguistic elements to make her poem interesting.

In our community, lullabies are common. It is a cradle song or a soothing song to calm children, lull them to sleep. Among the Somali community, a woman who cannot sing or recite a lullaby poem is considered to be lazy and disorganized. Therefore, lullabies in form of poetry is common.

Marcela: What do you think Dahabo?

Dahabo: Somalia is a nation of poets; this is true because our parents used poetry in different ways as follows:

Culture preservation: Our people used poems to preserve our culture and ways. The ways we dress, eat, and dance as Somali communities. It helps to understand every generation that comes after the others. It also preserves how we hold marriage ceremonies from clan to clan. A common culture is communicated through the poetry.

Mobilization (colonial era): In the colonial era, Somalia was colonized by two countries, Italy and Britain. They divided Somalia into two parts: North taken by the British and South by Italy. Sayyid Abdallah Hassan was a poet who mobilized Somali people to refuse colonization from those countries. The mobilization started from the North. By 1960, the whole Somali country became independent with the help of the poets through reciting in our mother tongue; it was direct and indirect communication.

Good values and attributes: In my home country, most of my people were pastoralists and farmers and they were independent people. A few were educated. Poetry is what I can say Allah bestowed Somali people with, because they are able to recite poetry and epics. The poems talk about the good values women have had, also the importance of camels in the Somali nation. Women were well respected as were elders and we have many poems that describe how valued they are in society. Hawa Tako is one of the famous Somali women who participated in the independence of our nation.

Patriotism: During colonization period, Somali youth (SYL) were the heroes of our nation where they measured patriotism through poetry and got many other youths joining together to confront the British and Italian authorities until Somalia turned into a democratic state. They later gave a hand to support other African countries gain independence, like---South Africa, Kenya, Angola, Uganda, Mozambique and many other countries. Magol is a poet that participated to wake Somali men from sleep and help African countries through a song. Also, Asha Lul is another Somali woman poet and she said:

Oh Mogadishu, your heroes are gone / I beg you then, I will pray and you say a man / May Allah send us a man of courage of truth / Who treats us equally, share the milk fairly

Somali communities liked milk that is why she used that example.

Public awareness for migration: After the civil war broke out, Somali people scattered in the globe. Somali people tried to save their lives from war and chose to cross the Mediterranean Sea and reach a country where they could live peacefully. Unfortunately, many died at sea. Therefore, Cultural and Pedagogical Inquiry, Summer 2020, 12(1), pp. 134-148

ISSN 1916-3460 @ 2020 University of Alberta http://ejournals.library.ualberta.ca/index.php/cpi/index 
poets started poems that described the harmfulness of migration, advising youth not to sacrifice their lives with this horrific danger.

Love: My mother told me that when she was 16 years old, my father expressed his love for her in poetry where he recited and she listened; this is how they used to do it, phones were not there and men came face to face with the ladies. This was how marriage proposals happened.

However, for us now, we are not aware about reciting as we don't know how to compose poems. Due to where I'm living, learning a curriculum which is far away from my home curriculum increases the difficulty.

Entertainment: Also, as part of childhood, my mother recited poems to me and my siblings during the night. When she recited, usually tears came out because she was from a family who were farmers and she loved to recite poems related to farming and cultivation and cows. Through this, I have learnt how my mother was happy before the war broke out which turned her life into a sorrowful one. As children, we adapted to live a life that has no meaning because we don't know more about Somalia except for my elder sister and brother.

Dahabo: Mohamed, when we arrived in Kenya everything changed especially our culture. Before, our people used to communicate through poems by expressing their feelings but currently people use speech that has no value in our culture. The young generation also do not understand the importance of poetry.

Mohamed: You hit the nail on the head Dahabo.

Marcela: Hard points! Now, would you not say there is still poetry in the young generation's homes or in community gatherings?

Mohamed: We use poetry in community gatherings like weddings.

Marcela: How about in homes?

Dahabo: Here in Dadaab not much, but Somalia is full of poets.

Mohamed: Old people use poetry at home and the youth listen to it.

Dahabo: My Mom says she remembers when Somalia was Somali and people were human then. She used to tell us how people, groups, individuals and community at large gathered in ceremonies and recited poetry while others enjoyed listening. When I heard such stories from home, I used to look at YouTube and listen to poetry from a famous poet but mostly I did not understand the meaning, although I am Somali and the language they were using is my home language, this sometimes bothers me deeply.

Marcela: From what you are saying Mohamed, old people are passing on traditions and, Dahabo, you give the example of your mother passing on culture. You also went to YouTube to listen to poets. When I asked the class to watch 'Home' by Warsan Shire and write a poem as reflection, I was so impressed and moved by the way you and your peers wrote poetry with so much grace and ease, as if poetry was at the tip of people's thoughts and capacities. Now I understand more; it seems to me that poetry continues to be in Somalis' hearts despite being in the camps, which is not home, and the schools' curricula is not including your culture.

Cultural and Pedagogical Inquiry, Summer 2020, 12(1), pp. 134-148

ISSN 1916-3460 ( 2020 University of Alberta

http://ejournals.library.ualberta.ca/index.php/cpi/index 
Dahabo: We can only write in English, but in terms of our mother tongue it's very hard due to it not being part of the curriculum. We Somali communities bear in mind that we are from a nation of poets and we respect the culture, norms and values from our ancestors.

Deko: In addition to what Dahabo and Mohamed stated, I do agree Somalia is a nation of poetry. I am inspired by listening to Somali poetry on YouTube and in community gatherings. I would add the following to what has been said:

[Firstly]: We use poems to end revolutions, where poets will describe the disadvantage towards humans and ecosystems, and where and how the revolt began and happened. The reciters will open windows for warriors that help them to keenly observe their actions and the rebels will start regretting their past actions, and develop love for the worries and dreams of the reciters.

[Secondly]: Our people predict through poetry what will happen by either observing or seeing how things are going on. Some predictions are about changes in the seasons; they predict changes by observing the stars in the sky. There are stars that appear in certain areas of the sky and if those stars do not seem to be in their usual place they say, we must expect something different, and those differences do occur. These changes become visible to everyone and people have an opportunity to do something before the opposite happens. Like, for example, if they are in the rainy season and the poets had predicted drought based on how the stars moved from their original position towards the opposite direction, it would be a chance for people to migrate when the stars that predict rain had changed places.

[Thirdly]: Our people used to predict floods through poetry as well, for example, they would warn of its effects against humans, like not to settle between the sea and river. We are all aware the seas do not move their base, but when there is ultra-high frequency of rain, a lot of water will move from the sea towards lower areas and may occupy the space of the rivers, and those humans around it will suffer seriously. Some might lose their lives, properties, land and many other losses. Our poets normally predict and warn against it.

[Fourthly]: Our poets normally use poetry to encourage, basically the youth, because youth are flexible and easy to change, so they encourage them to know their steps, actions, ideas and thoughts. To be loyal to their religion, culture and norms since they are the umbrella of the family, community, country and the entire world. They are the future generations; the ones that will bring change to the current responsibility holders and we are eager to leave for them a peaceful world for them to be safe without distractions.

Marcela: Thank you Deko, you add very thoughtful and interesting points here. Yours, Mohamed's and Dahabo's contributions help me understand the role poets have played and continue to play in Somali culture. 


\section{IN CLOSING}

\section{Marcela:}

Dear Poetic Friends,

I would like to thank you for your willingness to engage in this conversation which we have been able to accomplish across thousands of miles, thanks to our cellular phones and WhatsApp. As a teacher, I learned much from you and your fellow classmates throughout the duration of the course and I have continued to learn through this dialogue. You and your colleagues asked questions, contributed insights, and challenged me and each other about language, loss, home, refuge, schools and community-life. Now, one year after the course ended, I feel I have gained new insights through this conversation and by your willingness to share your views about your poems, your feelings about home and language, your community knowledge and your thoughtful understanding of your heritage and culture.

When I planned the course, I was hoping for writings from you and your classmates that would speak about home and would likely refer to home language and the loss of it. Honestly, I have been, and continue to be, impressed by the quality and depth of yours' and your colleagues' poems and writings. Also, the trust that you all demonstrated in your willingness to engage in reflective learning online, has been an important pedagogical lesson for me that will likely change my teaching from now on.

"Through dialogue, the teacher-of-the-students and the students-of-the-teacher cease to exist and a new term emerges: teacher-students with student-teachers. The teacher is no longer merely the-one-who-teaches, but one who is himself taught in dialogue with the students, who in turn while being taught also teach. They become jointly responsible for a process in which all grow." (Freire, P. 2000:80)

After the course ended, I tried to find out more about Somali poetry. So far, I have read Said Samatar's: Oral Poetry and Somali Nationalism, The Case of Sayyid Mahammad Abdille Hassan (1982). I have also read The Prophet Camel's Bell (1988) and A Tree for Poverty (1993), two books by Margaret Laurence, a much-loved Canadian writer, who spent time in the early 1950's in Somalia and wrote about Somali poetry. Your responses to my questions about Somalia being a nation of poets confirm and extend these readings and illuminate the meaning and depth of your literary heritage as a people.

I thank you again for agreeing to share your experiences, your poetry and your knowledge in this conversation, and for your willingness to enter in this writing adventure.

*The BHER Project is an international collaboration between Canadian/Kenyan universities and NGOs working together to provide internationally recognized certificates, diplomas and degree programs to refugees and locals in the refugee encampments of Dadaab, Kenya. www.bher.org

**Mohamed Duale, PhD student, Faculty of Education, York University, Toronto, ON, Canada. ***The Story Telling Class. (2009). Sedna Pictures. Winnipeg, MA.

Cultural and Pedagogical Inquiry, Summer 2020, 12(1), pp. 134-148

ISSN 1916-3460 @ 2020 University of Alberta

http://ejournals.library.ualberta.ca/index.php/cpi/index 


\section{References}

Freire, P. (2000). Pedagogy of the Oppressed with an introduction by Donaldo Macedo. New York-London: Continuum.

Freire, P., \& Macedo, D. (1987). Literacy: Reading the Word and the World. South Hadley, MA: Bergin \& Garvey.

Laurence, M. (1988). The Prophet Camel's Bell. Toronto, ON: McClelland \& Stewart Ltd.

Laurence, M. (1993). A Tree for Poverty. Hamilton, ON: McMaster University Library Press.

Lee, E., Menkhart, D., \& Okazawa-Rey, M. (2008). Beyond Heroes and Holidays: A Practical Guide to K-12 Anti-Racist, Multicultural Education \& Staff Development. Washington, D. C. Teaching for Change, $2^{\text {nd }}$ edition.

Samatar, S. (1982). Oral Poetry and Somali Nationalism, The Case of Sayid Mahammad Abdille Hassan. Cambridge University Press.

\section{Videos:}

Farah, N. and Achebe, C.:

https://yorku.kanopy.com/video/writers-talk-chinua-achebe-nuruddin-farah www.worldcat.org/title/writers-talk-chinua

Shire, W. (2011). Home is the Barrel of the Gun: https://www.youtube.com/watch?v=ybTM-aaJxS0 